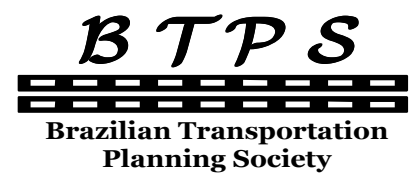
Journal of Transport Literature
Vol. 8, n. 2, pp. 325-348, Apr. 2014
Research Directory

JTL|RELIT

www.transport-literature.org ISSN 2238-1031

\title{
Improving post-sale reverse logistics in department stores: a Brazilian case study
}

[Melhorando a logística reversa de pós-venda em lojas de departamento: um estudo de caso brasileiro]

\author{
Diana Mery Messias Lopes, Márcio de Almeida D'Agosto, \\ Amanda Fernandes Ferreira*, Cintia Machado de Oliveira \\ Federal University of Rio de Janeiro - Brazil
}

Submitted 8 Apr 2013; received in revised form 29 Sep 2013; accepted 18 Oct 2013

\begin{abstract}
Post-sale reverse logistics has grown in importance in the supply chain. As a contribution to scientific innovation, we present a structured procedure for reverse supply chain management of goods after sale. In addition, a comparison is made between the structures of direct supply chains by checking the similarity in terms of transport operations, inventory management and information management, which allows its application in the case study. This paper aims to suggest a procedure to structure the reverse logistics chain which is based on Process Management and consider three basic levels: Product Entry Management, Resource Management and Performance Management in the Reverse Logistics Chain. A bibliographical and documentary review was conducted in addition to a field research with a group of three department stores. The data collected from the companies using questionnaires and interview shows that the application of the procedure suggests that a better structuring of management in post-sales reverse logistics in the retail market can improve financial results in companies by contributing to reduce product returns and consequently its costs, improve efficiency in inventory and storage management, improve assets usage, increase revenue and promote social benefits such as donation of the products which was used and had been returned for charity.

Key words: process management, reverse logistics, retail.

\section{Resumo}

A logística reversa tem crescido em importância na cadeia de abastecimento. Como contribuição científica inovadora, apresenta-se, a partir de uma revisão bibliográfica do processo de gestão da cadeia logística reversa, um procedimento estruturado para gestão da cadeia logística reversa de bens de pós venda. Adicionalmente é feita uma comparação com as estruturas das cadeias logísticas diretas, verificando-se a similaridade em termos de operações de transportes, gestão de estoque e gestão da informação, o que permite sua aplicação no estudo de caso. Este trabalho tem como objetivo sugerir um procedimento para estruturar a cadeia de logística reversa, que é baseado em Gestão de Processos e considera três níveis básicos: Gestão de entrada do produto, Gestão de Recursos e Gestão do Desempenho na Cadeia Logística Reversa. Uma revisão bibliográfica e documental foi realizada, além de uma pesquisa de campo com um grupo de três lojas de departamento. Os dados coletados dessas empresas através de questionários e entrevistas mostram que a aplicação do procedimento sugere que uma melhor estruturação da gestão em logística reversa de pós-venda no mercado de varejo pode melhorar os resultados financeiros nas empresas, contribuindo para reduzir os retornos de produtos e, conseqüentemente, seus custos, melhorar a eficiência no estoque e gerenciamento de armazenamento, melhorar o uso de recursos, aumentar a receita e promover benefícios sociais, como por exemplo a doação dos produtos que foram usados e foram devolvidos para a caridade.
\end{abstract}

Palavras-Chave: gestão de processos, logística reversa, varejo.

*Email: amandafernandes@pet.coppe.ufrj.br.

\section{Recommended Citation}

Lopes, D. M. M., D'Agosto, M. A., Ferreira, A. F. and Oliveira, C. M. (2014) Improving post-sale reverse logistics in department stores: a Brazilian case study. Journal of Transport Literature, vol. 8, n. 2, pp. 325-348.

- JTL/RELIT is a fully electronic, peer-reviewed, open access, international journal focused on emerging transport markets and published by BPTS - Brazilian Transport Planning Society. Website www.transport-literature.org. ISSN 2238-1031.

This paper is downloadable at www.transport-literature.org/open-access. 


\section{Introduction}

This paper aims to suggest a procedure for structuring the reverse logistic chain utilizing a bibliographical and documentary review taking into consideration structural aspects of postsales reverse logistics in the retail market, particularly in department stores.

Reverse logistics has been recognized as a source of competitive advantage for companies in the current business environment. The increasing importance of reverse logistics is stimulated by a variety of factors, among which Leite (1998), Rogers and Tibben-Lembke (2001) and Lacerda (2002) list the following: (1) pressure imposed by law; (2) the need for reducing costs; (3) reduction of products and services lifecycles; (4) proposition of a different corporate image and (5) raising of environmental awareness.

However, reverse logistics is still not treated by companies as an established process in the logistics chain. This is evident when we look at how companies treat the issue. In many cases there is no planning for this process, making it difficult for companies to control achieved results and, consequently, making it impossible for them to define actions to improve this flow (Leite, 2002).

As reverse logistics has grown in importance in the supply chain and its efficiency has been a result of financial improvements and customer satisfaction, it becomes necessary to study its processes and activities in an organized manner (Ballou, 2001). As a contribution to scientific innovation, we present a structured procedure for reverse supply chain management of goods after sale by reviewing the literature of the process of reverse supply chain management. In addition, a comparison is made between the structures of direct supply chains by checking the similarity in terms of transport operations, inventory management and information management, which allows its application in the case study. Importantly, based on the literature review, we could verify that no other study made similar contribution. This work aims to propose a structure for managing the processes of post-sales reverse logistics in companies in the retail market. To achieve this goal a bibliographical review was done. A documentary research and data collection were conducted about operational practices in department stores. Based on this bibliographical review a proposal for structuring the reverse 
logistics flows in retail trade a proposition with a selected group of department stores in Brazil were done so as to confirm its adequacy. Three companies had been chosen to be a part of this research to answer a questionnaire and participate in an interview. This study showed that in some department stores in Brazil there exist a partially structured reverse flows.

This work is divided into 5 sections. Section 1 discusses theoretical definitions and concepts about reverse logistics collected through a bibliographical review of recent works (from the last 5 years). Next, Section 2 presents a proposition for structuring the process management of post-sales reverse logistics; this proposal is applied to a selection of companies in Section 3 and results are presented in Section 4. Finally, in Section 5 conclusions are presented.

\section{Reverse logistic process}

The degree of structuring of the reverse logistics flow can be defined in function of: the existence of organizational practices involving the procedures in the steps of product return; the relationship and information exchange between companies involved in the reverse logistics; and the amount of resources made available for product return operations (Rogers and Tibben-Lembke, 1998; Stock, 1998; Kopicki et al., 1993; Leite, 2003; De Brito, 2004). In this case, the steps in the reverse logistics flow are: collection, separation/selection, processing and return to market or disposal (Biazzi, 2002).

In Figure 1, we present a sequence of steps where we highlight the structuring sub-processes and the activities of each sub-process, especially disposition and the activities of standardization of product entry in the reverse logistics flow (Reverse Logistics Executive Council - RLEC, 2001). 
Sub-Processes

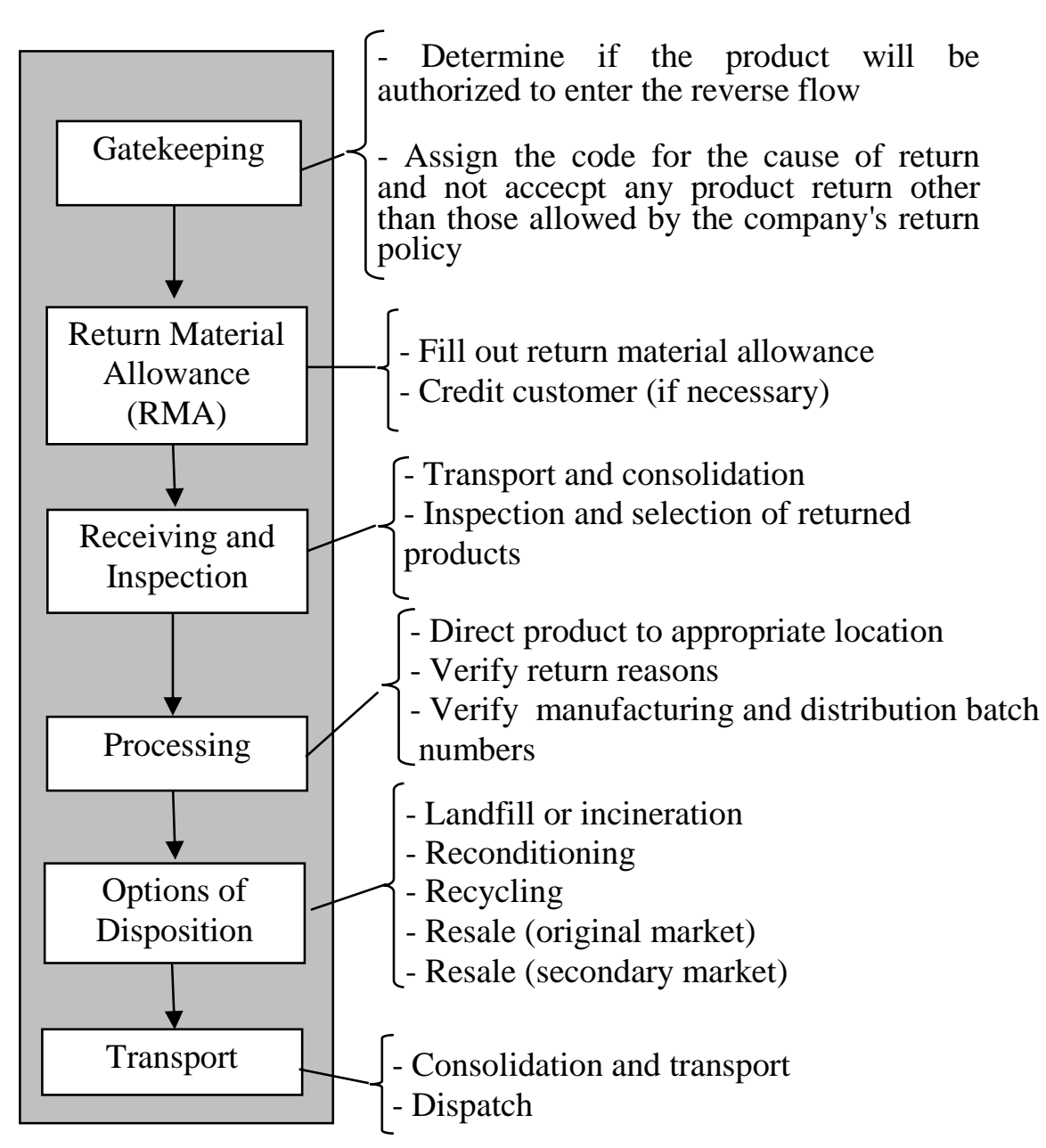

\section{Figure 1 - Steps of a product return flow ${ }^{1}$.}

According to the definition by Rogers and Tibben-Lembke (1998), gatekeeping is the management of the entry points in the reverse logistics chain, a step which represents the first critical factor to make the reverse logistics process profitable. In this way, the first action to be taken is to establish a policy that considers what can be accepted in this reverse logistics flow.

\footnotetext{
${ }^{1}$ Reverse Logistics Executive Council - RLEC, 2001
} 
The authors state that the Return Material Allowances (RMA) must be standardized, presenting at least the reasons for return. This information can be used to generate good communication between suppliers and customers; they can also be automated, making it easy to collect and store the information for later use.

According to Lacerda (2002), the way the reverse logistics process is planned and managed determines its efficiency. The aspects that contribute to the performance of the reverse logistics process, selected by this author and identified as critical, are the following: (1) the existence of good entry controls; (2) standardization and mapping of processes; (3) reduction of cycle time; (4) implementation of information systems; (5) planning of the logistics network and (6) development and maintenance of collaborative relationship between customers and suppliers.

According to Martins (2005), well-functioning reverse logistics depend on aspects which resemble the ones defined by Lacerda (2002), but adding the following: (1) costs management and (2) marketing strategies, which will be described below.

To Guarnieri et al. (2006), the activities traditionally carried out at distribution centers to manage logistics may also be used in reverse logistics. These activities, according to Banzato (1998), are: (1) workforce planning and allocation, gatehouse control and product receiving; (2) control of products storage and inventory; (3) product inspection and quality control; (4) product transfer and expedition; (5) container storage and control, (6) report generation and (7) database creation.

Table 1 presents aspects that must be observed in order to create a structured reverse logistics channel, according to Leite et al. (2005).

When compared to other bibliographical references presented, Leite et al. (2005) aims to classify the aspects that attempt to structure the reverse logistics activity and are applicable to different business sectors according to the main functions of logistics: transport, inventory management and information processing; and according to business marketing. 
Table 1 - Observable aspects in the structuring of a reverse logistics channel ${ }^{2}$.

\begin{tabular}{|c|c|}
\hline General Procedures & Storage and Resources \\
\hline Well-defined return procedures & Specific locations dedicated to product returns \\
\hline Control over receiving of returned products & Specific locations for remanufacturing \\
\hline Classification and quantification of returns & Control over storage costs of returned products \\
\hline Codification of returns by controls & Personnel dedicated to product returns \\
\hline Consolidation procedures for returns & Equipment dedicated to product returns \\
\hline $\begin{array}{l}\text { Well-defined selection and disposition } \\
\text { procedures }\end{array}$ & $\begin{array}{l}\text { Information Systems dedicated to product } \\
\text { returns }\end{array}$ \\
\hline Transport & Revaluation \\
\hline Well-defined means and vehicles & Stimulates the handling of product returns \\
\hline Well-defined frequency and routes for collection & Provides corporate image improvement \\
\hline Well-defined product conditioning & Provides regaining of value \\
\hline Product return priorities & Known costs and revenues \\
\hline Control over transport costs of returned products & Existence of well-defined secondary market \\
\hline Contracts & Information Flow \\
\hline Existence of return contracts within the chain & Existence of an information system for returns \\
\hline Existence of outsourcers hired for revaluation & Operations are computerized \\
\hline Existence of a payment and reimbursement flow & Information is provided to other company areas \\
\hline
\end{tabular}

As for the aspects presented in Table 1, additional considerations must be presented.

(i) Transport - relates to the logistics function of transport and the attempt to identify the reverse logistics flow according to the modes of transport and the collection procedures (route, frequency, priorities and cargo conditioning). Its costs must be known and its optimization must be pursued so that productive efficiency and costs reduction are achieved;

\footnotetext{
${ }^{2}$ Leite et al. (2005).
} 
(ii) Storage and Resources - are mainly associated to the logistics function of inventory management, which involves control over returned products receiving, standardized consolidation, quantification and categorization of products by product type and disposition to specific storage locations. Storage costs must be strictly controlled. The resources considered here are workforce and cargo handling equipment;

(iii) Information flow and contracts - these are mainly related to the logistics function of information management, which considers the need to establish information systems that are especially dedicated to the handling of returned products, including the formalization of how return flows are generated, restored and controlled;

(iv) General procedures - are related the logistics functions of information and inventory management by means of standardization and control of how returned products enter the reverse logistics chain;

(v) Revaluation - relates to business marketing and concerns the revaluation of returned products in financial and corporate image terms. This series of activities stimulates the careful handling of returned products with the disposition being defined and controlled by the company.

The bibliographical review considered until here represents a contribution to the comprehension of how different authors treat the structuring aspects of the reverse logistics chain. However, we still have not considered the retail trade activity, which according to Kotler (2000), is every activity in which products or services are sold directly to final consumers, for personal and non-commercial use. The location where products or services are sold (stores, street or customer's residence) is not important. Also, all the manners in which these products or services are sold are included in the concept of retail trade, be it through personal, mail or telephone sales.In order to complement the above presented structuring aspects of the reverse logistics chain we have conducted a non-exhaustive bibliographical review on seven works that present case studies about reverse logistics applied to retail trade. Chaves et al. (2005) and Chaves et al. (2008) are national articles, while Autry et al. (2000), De Koster et al. (2002), Valstad (2002), Horvath et al. (2005) and Moise (2008) are international articles. 
The structuring aspects found in these case studies were compared with each other and with the results from the previous bibliographical review and the following additional aspects were found: (1) strategic role, meaning the definition of reasons for the development of reverse logistics; (2) performance indicators, considered as instruments to measure performance and to check if the company's established goals are being achieved; and (3) liquidity problems due to financial operations; these take place when the flow of money occurs after the product is returned to a previous member of the chain or when the product is sold.

\section{Proposing a structured reverse logistics chain}

Considering the bibliographical review presented above (Section 2), we propose that the structuring of a reverse logistics chain for the retail market be based on Process Management, considering three basic levels: Product Entry Management in the Reverse Logistics Chain; Resource Management in the Reverse Logistics Chain; Performance Management in the Reverse Logistics Chain. The second section is subdivided into four sub-sections: Transport Management (inbound), Transport Management (outbound), Inventory Management and Information Management in the Reverse Logistics Chain. These three levels and their subdivisions consider managerial aspects, directives and activities that focus on operational aspects. The following is a detailed description of the subdivisions which helps to understand their application.

\subsection{Product entry management in the reverse logistics chain}

The purpose of Product Entry Management in the Reverse Logistics Chain is to assure there are policies concerning what can be accepted in the reverse flow. It can be done, for example, by means of a well-defined exchange policy which also helps to maintain customer loyalty. Among its functions we highlight knowing the reason why the product is being returned, verifying what condition the product is in and the definition of which exchange procedure pleases the customer (Biazzi, 2002). 
Table 2- Process management structuring proposed for use in the reverse logistics chain in the retail market.

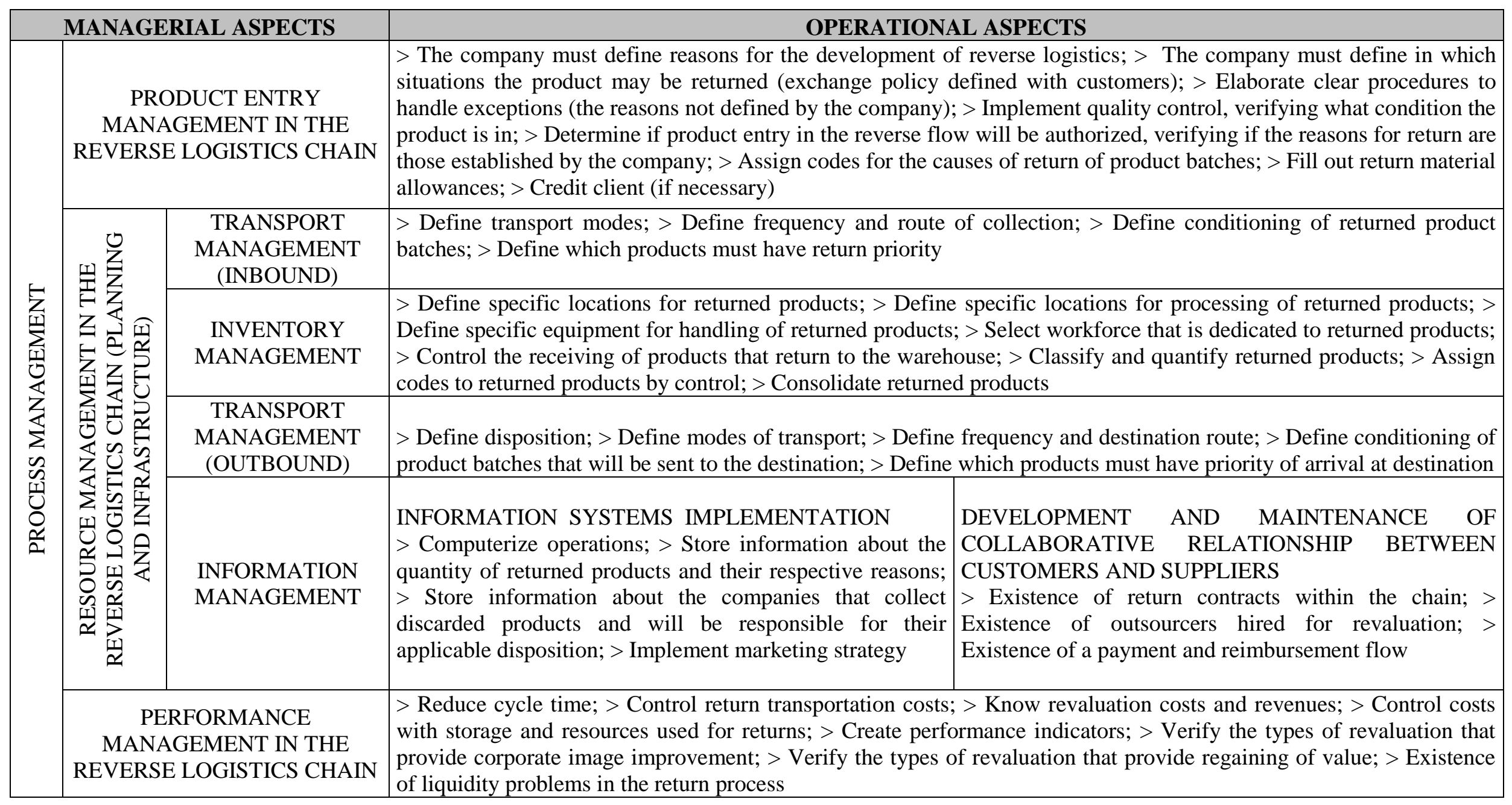




\subsection{Resource management in the reverse logistics chain}

This activity is subdivided into Transport Management, Inventory Management and Information Management in the Reverse Logistics Chain. Transport Management is one of the main logistics functions, since it generates the highest logistics costs in most of the organizations. In the case of reverse logistics, transport problems are more complex because routes and routines are lowly predictable, costs are not always fully understood, financial aspects are somewhat unpredictable and negotiations are less direct (Leite, 2003). In order to lessen the uncertainties concerning specification of the transport activity in reverse logistics chains, one must create directives and activities that involve the identification of the modes of transport, the routes and itineraries, the conditioning of product batches and the definition of product return priorities, as mentioned in Table 2.

Inventory Management, also one of the main logistics functions, establishes directives and activities involving the process of controlling inventory, product handling and storage. It also attempts to control the receiving of all products that are returned for different reasons and from different regions so they can be identified, sorted and forwarded to the reverse channel that offers the best regained value (Leite, 2003).

Finally, Information Management is subdivided into two groups of activities: Implementation of Information Systems and Development of a Collaborative Relationship between Customers and Suppliers. The first promotes the organization of information generation and processing about returned products, comprehending information that will be useful for retailers, distributors and suppliers. The electronic management and transfer of information provides an opportunity for reducing logistics costs through better logistics coordination (Figueiredo et al., 2000). The second, deals with the regulation of the information generation process through contracts and agreements between service providers and customers and also payment and reimbursement flows.

\subsection{Performance management in the reverse logistics chain}

As all enterprises need planning, operation and control, performance analysis can be considered, primarily, as a tool for enterprise control that provides feedback for operation and 
planning, prevention of eventual problems, elimination of the existing ones and determination of efficiency and efficacy in the reverse logistics flow.

As seen in Table 2, Performance Management in the Reverse Logistics Chain involves activities and directives related to measurement of cycle time, transport and storage costs, and the revaluation potential of returned products in the reverse logistics chain. Besides that, Performance Management also deals with performance attributes that consider time and money resources and the potential to capture revenue (revaluation).

The application of the Process Management proposition will be tested in the next section which will reveal the existence or not of structured reverse logistics flows in a selection of Brazilian department stores, from the product entry point in the reverse chain until its final destination.

\section{Case studies}

Documentary research and data collection were conducted about operational practices in department stores with a focus on the analysis of the structuring of reverse logistics flows in retail trade. Additionally, by means of open interviews (Yin, 2001) and direct observation, we have verified the adequacy of processes according to Table 2 .

In order to choose the companies, the following criteria were established: (1) companies that sell diverse products - clothes and personal accessories, bed, bath and table accessories and electronic equipment; (2) companies that operate in the whole country, but have stores in Rio de Janeiro so that on-site investigation could be conducted.

In a preliminary research, we have found 2,927 department stores operating in the retail market in Brazil, 324 of them being in Rio de Janeiro. However, we have found 6 companies that met both our criteria: Renner, Riachuelo, Marisa, Company D (this company required anonymity), C\&A Modas Ltda. and Lojas Americanas S.A., of which the last 3 agreed to take part in our research; this made it possible for us to compare reverse logistics chains in department stores of different sizes, as will be described next. 
Company $\mathrm{D}$ is active for more than 50 years. Its stores network comprises 41 stores distributed throughout the states of Rio de Janeiro, Espírito Santo, Minas Gerais, Sergipe, Pernambuco and Alagoas operating on the following segments: clothing (women, men and children), toys, bed, bath and table products and home utilities.

Founded in 1929, Lojas Americanas S.A. currently comprises 469 stores located in the most important cities in Brazil, trading more than 60.000 sections. The company operates as a chain of discount department stores - the main characteristic of this model is the availability of products from big brands with competitive prices in relation to other competitors - in the following segments: clothing (women, men, children), toys, bed, bath and table products, home utilities, convenience food, perfumery and cosmetics.

C\&A Modas Ltda. was created in 1841 and is present in 19 countries, with more than 1,000 stores. In Brazil, its activities started in 1976 and currently there are 170 stores. It processes from around 300 to 400 thousand pieces a day in the following segments: clothing (women, men, children) and accessories (belts, bags and wallets). Besides these articles, the company has been specializing in new segments such as cosmetics, perfumery and technological devices (cell phones, digital cameras and DVDs)

A questionnaire was developed and it served as guidance for the interviews conducted at the companies between October 2008 and January 2009. Before conducting the interview, the respondents were informed of the nature of the research and the questions were asked without inducing answers, always leaving the opportunity for pertinent comments.

For each question there were answers and justifications for these answers. The answers that gave full response to asked aspect were attributed a value of "1", otherwise they were attributed a value of "0". The adoption of this premise allowed for the quantitative assessment of the answers. We have attributed the same level of importance to all sections in the questionnaire.

\section{Results analysis}

Based on the proposition presented in Table 1, on which the field research was founded, we present next the obtained results. 


\subsection{Product entry management in the reverse logistics chain}

None of the 3 companies has established reasons for the development of reverse logistics (strategic role). On the other hand, all of them have an exchange policy based on the Brazilian Customer Defense Law (Código de Defesa do Consumidor), this situation being the first condition for management of product entry in the reverse logistics flow by means of a policy stating what can be accepted into this flow (Rogers and Tibben-Lembke, 1998).

At Company D the information that is controlled when the product returns to the distribution center states the type and the quantity of products. The information which is not controlled is that which regards the reason for the product return, a factor that hampers the identification of the causes by which customers return the products.

At Lojas Americanas S.A, the concern with customer service occurs only when a product must undergo repair and return to the customer. There is also no control as to what were the reasons of product returns by category.

As for C\&A Modas Ltda., its stores record the reasons for returns. The company defines in which situations exchanges are to be made. This information is stored in a database and the company's quality control department is able to identify the quantity, type, reason and respective suppliers of the returned products, enabling the prevention of potential returns and each store is responsible for the disposition of returned products.

In the case of Company D stores, the control of which products may be returned is limited to damaged products that are for sale at the store. In the case of Lojas Americas S.A., there are three types of documents to record product returns: a record of damaged products; a record of products to be repaired; and a record of products to be returned to their suppliers. In all cases there is not full data collection concerning the return of products by customers.

The percentage of positive answers in the aspects of Product Entry Management is presented in Figure 2, C\&A Modas Ltda. being the company that met most of the aspects, more than double compared to the other companies. Among the benefits of this structuring, according to Biazzi (2002), there is the possibility of knowing the customers better and defining an exchange procedure that will please them, keeping customer loyalty. Lacerda (2002) also claims that access to this type of information favors the adequate identification of returned 
products and allows them to follow the right reverse flow, preventing the entry of unnecessary sections. To Rogers and Tibben-Lembke (1998) and RLEC (2001), the storage of this information will ensure its future use.

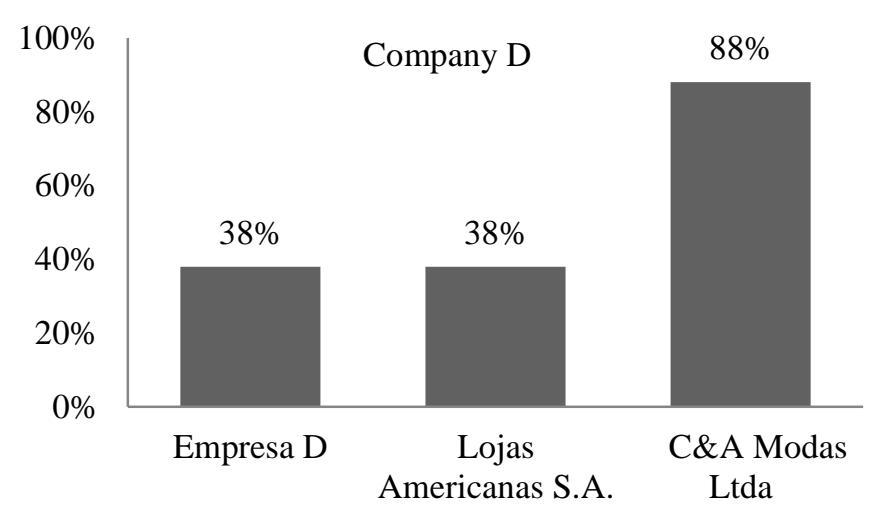

Figure 2 - Positive aspects of Product Entry Management

\subsection{Resource management in the reverse logistics chain}

Regarding Transport Management, to all three companies, the transport used in the reverse flow is the same as the one used in the direct flow. Thus, the mode of transport and the frequency of direct distribution are the same used for product returns. Given this, there is no specific planning or practices, conditioning definitions and priority classification for product on return transport.

The percentage of positive answers in the aspects of Transport Management (inbound) is presented in Figure 3. All three companies present the same level of structuring in Transport Management (inbound).

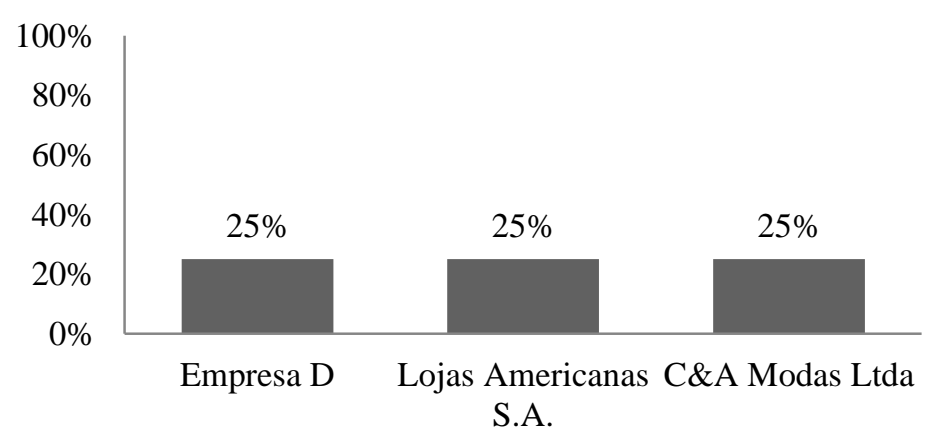

Figure 3 - Positive aspects of Transport Management (inbound) 
Regarding inventory management, Company D presents control over receiving products that are returned to the distribution center, consolidating them and quantifying them by type. This confirms the existence of a specific infrastructure for this activity. At Company D, there is a specific location for the storage of returned products and also workforce and product handling equipment specially dedicated to handling this type of product.

Company D also practices revaluation of returned products. This occurs either for financial revaluation, associated to: product disposition to the original market for resale (transfer between stores), resale at the secondary channel, recycling (in the case of cartons and plastic packaging), product return to supplier and packaging reuse; or for corporate image revaluation, related to disposition for donation and recycling. This information stimulates the careful handling of returned products with the disposition being defined and controlled by the company and this reflects positively on corporate image.

The controls in practice for returned products to the distribution center in the case of Lojas Americanas S.A. occurs in a different way, since when products arrive at the distribution center they are sorted by supplier type, not by product type. Then, return reasons are identified in order to establish product disposition, which may be: return to supplier, technical assistance, resale at stores and disposal. We highlight that the types of disposition given to returned products at Lojas Americanas S.A. are associated primarily to the financial revaluation of products.

At C\&A Modas Ltda., on the other hand, the control of product returns to the distribution center is limited to packaging and product support sections (e.g., clothes hangers). The other products do not return to the distribution center, being a responsibility of the stores to define the disposition of those products which were not sold or that had some kind of problem, including the cases of product donation.

Lojas Americanas S.A. and C\&A Modas Ltda. have the same Inventory Management infrastructure as Company D. The difference is that C\&A Modas Ltda. aims to revaluate the returned product, by means of financial revaluation or corporate image improvement. It was observed the all three companies present the same level of structuring (90\%) of Inventory Management aspects, lacking only the coding of products by return reason (Figure 4). This structuring involves: control over receiving of returned products, standardized consolidation, 
quantification and categorization of products by product type and disposition to specific storage locations (Leite et al., 2005).

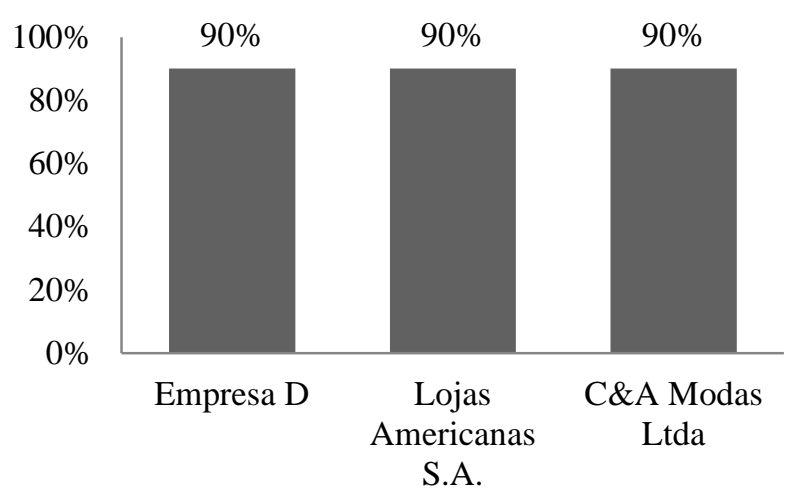

\section{Figure 4 - Positive aspects of inventory management}

The service of collecting returned products and disposed packaging at the distribution center is outsourced by all three companies (Transport Management - Outbound). Regarding Information Management at Company D and Lojas Americanas S.A., we could not verify the existence of any computerized operations or information on the reason of product returns by customers; the only recorded information was the quantity and type of returned products and the companies that collect disposed products and are responsible for their respective disposition

In the case of C\&A Modas Ltda., all operations related to products returning to stores or distribution centers are computerized. There is collection of information about product returns (as specified in Product Entry Management above) which allows for tracking of return flows, measurement of cycle time and supplier performance, enabling the generation of crucial information for negotiating with customers, improving performance and identifying customer abuse in product returns (Lacerda, 2002).

No marketing strategy related to reverse logistics could be verified at any of the three visited companies. According to Martins (2005), structuring the marketing channel stimulates product returns by customers, this may happen through discounts offered to the original customer, through the substitution of the used product by a new one (by presentation of the product that has reached the end of its lifecycle), or through any offer that aims to lead the customer to returning the disposed product. These products that are returned after being used 
may be donated to charity, turning into marketing strategy and contributing to a better corporate image before society on ecological and legal perspectives (Leite et al., 2005).

Regarding the Development and Maintenance of Collaborative Relationship between Customers and Suppliers, all three companies have product return contracts with suppliers. There are also outsourcing contracts with companies that take care of product revaluation. We have also verified the existence of payment and reimbursement flows with suppliers and outsourcers. The above information demonstrates the existence of integration in the reverse logistics chain and evidence of collaborative relationship between the links in the chain (Lacerda, 2002 and Martins, 2005).

The percentage of positive answers in the aspects of Information Management is presented in Figure 5. C\&A Modas Ltda. is the company with the highest level of structuring in Information Management, possibly beacuse it is the only one with computerized operations.

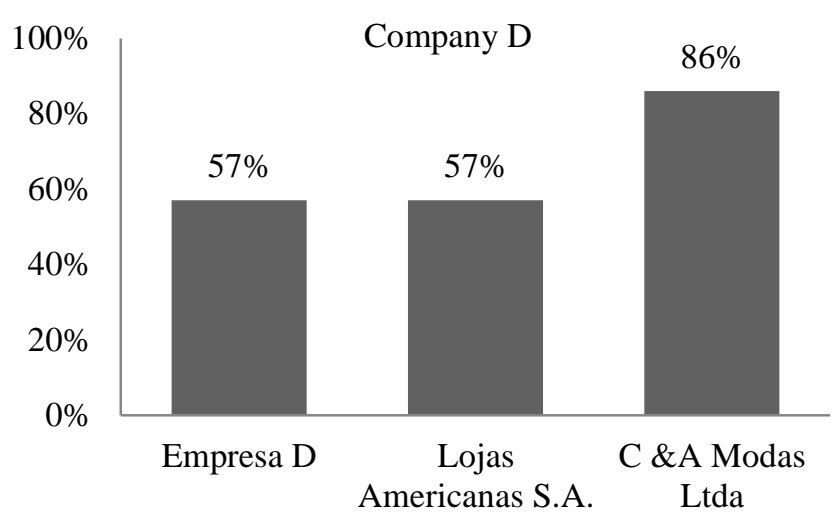

Figure 5 - Positive aspects of information management

\subsection{Performance management in the reverse logistics chain}

At Company D, there is no measurement of cycle time and transport costs are related to freight costs comprehending the transport from the distribution center to the stores and back to the distribution center. At this company, despite the fact there is control over the quantity of returned products, there is no knowledge of the total costs involved in product return operations; only the product revaluation revenue is known. There is no control over the costs involved in storage or resources used for the returns. This company does not measure revaluation types that improve corporate image, but knows the types that provide regained 
value.

Lojas Americanas S.A. does not have information about revaluation revenue and products regain value when they go to technical assistance. Concerning return transport costs, when products return from stores to the distribution center, the supplier pays the return freight, but when products are sent to repair, Lojas Americanas S.A. pays the freight.

As for C\&A Modas Ltda. we have verified control over storage costs and costs with return resources, as well as value recovery through reuse of packaging and product support sections (e.g., hangers), leading to a decrease in total return costs.

At all three companies we could not verify indicators to measure the performance of the reverse logistics process and there are also no cases of liquidity problems.

The percentage of positive answers in the aspects of Performance Management is presented in Figure 6. C\&A Modas Ltda. is better structured for Performance Management due to control of costs related to storage and resources used for returns.

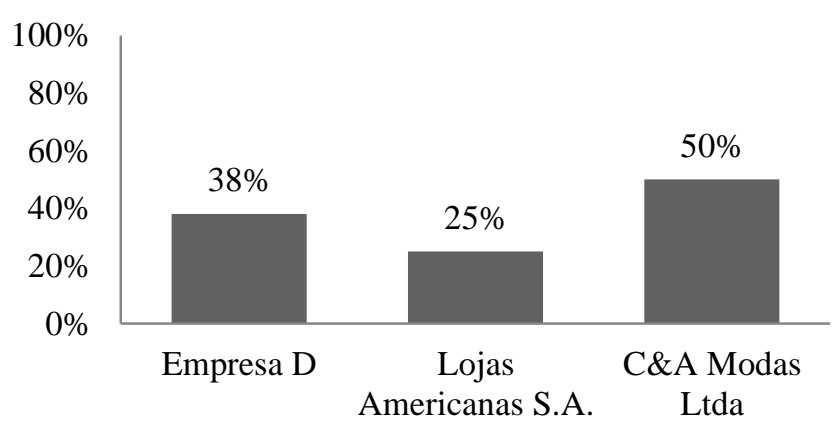

Figure 6 - Positive aspects of Performance Management

Figure 7 presents the total percentage of positive answers considering the whole Process Management Structuring (Table 2) under Managerial and Operational Aspects; it can be observed that C\&A Modas Ltda. is the company with the best structuring in the reverse logistics flow (17\% better than Company D and 20\% better than Lojas Americanas S.A.). 


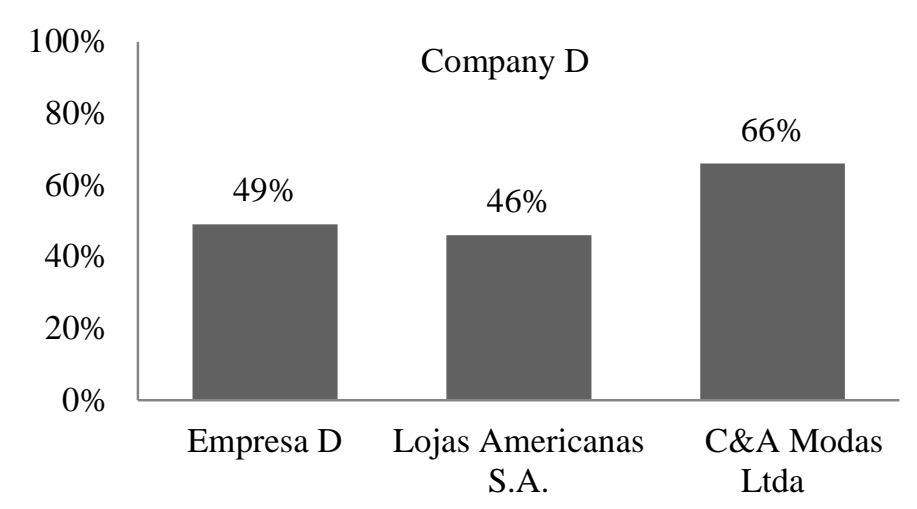

Figure 7 - Total positive aspects for all three companies.

Figure 8 presents a detailed description of positive aspects for all three companies in order to highlight differences and similarities between researched companies. In this context, C\&A Modas Ltda. achieved the highest level of structuring in Product Entry Management (50\% higher than the other companies). It also achieved the highest level in Information Management (86\%) and in Performance Management (50\%). Besides that, it achieved results equal to the other companies in Transport Management (inbound) (25\%) and Storage Management (90\%).

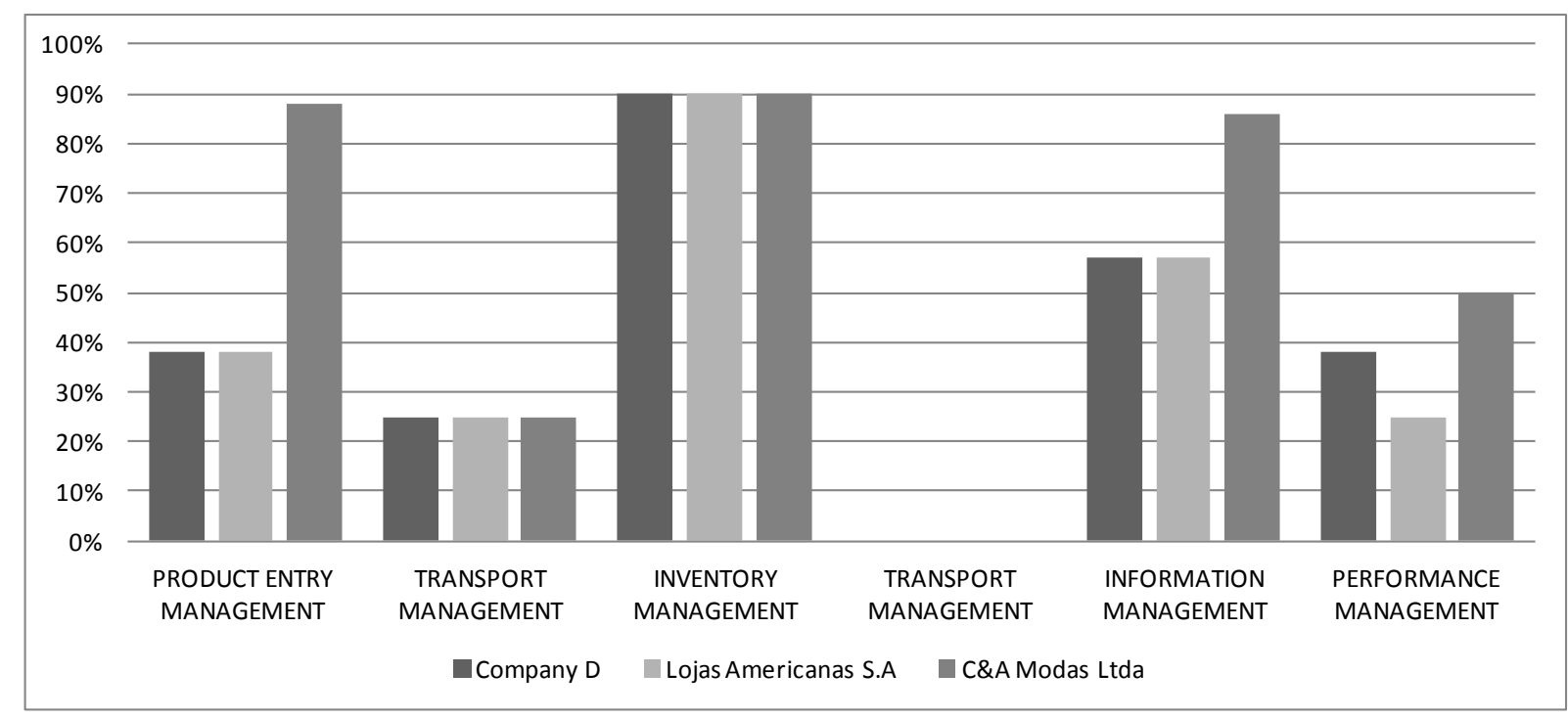

Figure 8 - Detailed description of positive aspects for all three companies.

Company D and Lojas Americans S.A. reached the same results in Product Entry Management (38\%), in Transport Management (25\%), in Inventory Management (90\%) and in Information Management (57\%). Only in Performance Management the results were 
different, Company D achieving 13\% higher than Lojas Americanas S.A.

The differences between the positive aspects of the three companies will be addressed in Table 3. It can be observed that C\&A Modas Ltda. has better control over Product Entry Management when compared to the other two companies; this increases the potential for reduction in product returns and consequently in costs. Regarding Performance Management, only C\&A Modas Ltda. controls costs related to storage and resources used for returns and only Lojas Americanas S.A. does not show concern with checking the types of product revaluation that improve corporate image. As for Information Management, C\&A Modas Ltda. has computerized reverse logistics, leaving its processes more accurate and faster, storing information that enables identification of product return causes.

Table 3 - Differences in positive aspects among companies ${ }^{3}$

\begin{tabular}{|c|c|c|c|}
\hline $\begin{array}{l}\text { Management } \\
\text { / Differences }\end{array}$ & $\begin{array}{l}\text { C\&A Modas Ltda. X } \\
\text { Company D }\end{array}$ & $\begin{array}{l}\text { C\&A Modas Ltda. X } \\
\text { Lojas Americanas S.A }\end{array}$ & $\begin{array}{c}\text { Company D X } \\
\text { Lojas Americanas } \\
\text { S. A. }\end{array}$ \\
\hline $\begin{array}{l}\text { Product Entry } \\
\text { Management } \\
\text { in the Reverse } \\
\text { Logistics } \\
\text { Chain }\end{array}$ & \multicolumn{2}{|c|}{$\begin{array}{l}\text { > Control over products that are returned by } \\
\text { customers } \\
>\text { Control over the quantity of returned products by } \\
\text { reasons } \\
>\text { Existence of a document to record return reasons } \\
\text { > Promotion of correlation between product type } \\
\text { and return reason }\end{array}$} & 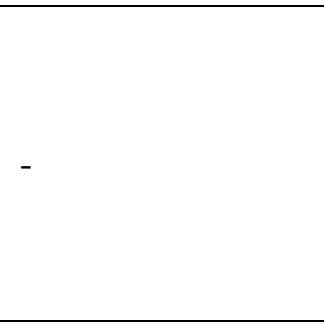 \\
\hline $\begin{array}{l}\text { Information } \\
\text { Management }\end{array}$ & \multicolumn{2}{|c|}{$\begin{array}{l}>\text { Computerized operations } \\
>\text { Storage of information on quantity of returned } \\
\text { products and their respective reasons }\end{array}$} & \\
\hline $\begin{array}{l}\text { Performance } \\
\text { Management } \\
\text { in the Reverse } \\
\text { Logistics } \\
\text { Chain }\end{array}$ & $\begin{array}{l}>\text { Control over costs } \\
\text { with storage and } \\
\text { resources used in } \\
\text { product returns }\end{array}$ & $\begin{array}{l}>\text { Control over costs with } \\
\text { storage and resources } \\
\text { used in product returns } \\
>\text { Verification of } \\
\text { revaluation types that } \\
\text { provide corporate image } \\
\text { improvement }\end{array}$ & $\begin{array}{l}>\text { Verification of } \\
\text { revaluation types } \\
\text { that provide } \\
\text { corporate image } \\
\text { improvement }\end{array}$ \\
\hline
\end{tabular}

Next, we present similarities in positive aspects (Table 4) and similarities in negative aspects (Table 5) among the three companies. It can be observed in Table 4 that all three companies had the most similar positive aspects in Inventory Management, demonstrating the importance given to receiving of products returned to the distribution center. Here we could attest control

\footnotetext{
${ }^{3}$ Note: (-) There are no similarities
} 
over product receiving, processing, storage and disposition. In Table 5, it can be seen that companies had the most similar negative aspects in Performance Management, showing that little importance is given to measurement and control of the reverse logistics process.

Table 4 - Similarities in positive aspects among the companies

\begin{tabular}{|c|c|}
\hline Management / Similarities & Company D / Lojas Americanas S.A. / C\&A Modas Ltda. \\
\hline $\begin{array}{l}\text { Product Entry Management in the } \\
\text { Reverse Logistics Chain }\end{array}$ & $\begin{array}{l}>\text { Existence of exchange policy with the customer } \\
>\text { Definition of the reasons why products are returned } \\
>\text { Control over the type of product that returns }\end{array}$ \\
\hline Transport Management (Inbound) & $>$ Definition of transport modes \\
\hline Inventory Management & $\begin{array}{l}\text { > Definition of specific locations for returned products } \\
>\text { Definition of specific locations for processing returned products } \\
>\text { Definition of specific equipment for handling of returned products } \\
>\text { Selection of workforce dedicated to returned products } \\
>\text { Control over the receiving of returned products at the warehouse } \\
>\text { Classification and quantification of returned products } \\
>\text { Consolidation of returned products } \\
>\text { Definition of disposition } \\
>\text { Control over returned packaging }\end{array}$ \\
\hline $\begin{array}{l}\text { Transport Management } \\
\text { (Outbound) }\end{array}$ & - \\
\hline Information Management & $\begin{array}{l}\text { > Storage of information about the companies that collect discarded } \\
\text { products and will be responsible for their applicable disposition } \\
>\text { Existence of return contracts within the chain } \\
>\text { Existence of outsourcers hired for revaluation } \\
>\text { Existence of a payment and reimbursement flow }\end{array}$ \\
\hline $\begin{array}{l}\text { Performance Management in the } \\
\text { Reverse Logistics Chain }\end{array}$ & $\begin{array}{l}>\text { Control over transport costs of returned products } \\
>\text { Verification of revaluation types that provide corporate image } \\
\text { improvement }\end{array}$ \\
\hline
\end{tabular}

Table 5 - Similarities in negative aspects among the companies.

\begin{tabular}{|c|l|}
\hline Management / Similarities & \multicolumn{1}{|c|}{ Company D / Lojas Americanas S.A. / C\&A Modas Ltda. } \\
\hline $\begin{array}{c}\text { Product Entry Management in the } \\
\text { Reverse Logistics Chain }\end{array}$ & $>$ No definition of reasons for the development of reverse logistics \\
\hline Transport Management (Inbound) & $\begin{array}{l}\text { > No definition of frequency and route of collection } \\
\text { > No definition of returned product batches conditioning } \\
>\text { No definition of which products must have return priority }\end{array}$ \\
\hline Inventory Management & $>$ No codification of returned products by reason of return \\
\hline $\begin{array}{c}\text { Transport Management } \\
\text { (Outbound) }\end{array}$ & $>$ All aspects are negative \\
\hline Information Management & $>$ No implementation of marketing strategy \\
\hline $\begin{array}{c}\text { Performance Management in the } \\
\text { Reverse Logistics Chain }\end{array}$ & $\begin{array}{l}\text { > No measurement of cycle time } \\
\text { > No knowledge of revaluation costs and revenues } \\
\text { process } \\
\text { > No occurrence of liquidity problems }\end{array}$ \\
\hline
\end{tabular}


As found in the results achieved through the case studies, none of the companies had $100 \%$ of positive answers, showing that their reverse logistics chains are partially structured. Through the comparison of data obtained from the verification of structured reverse flows, we could find that C\&A Modas Ltda. had the highest percentage of positive aspects and has the most structured reverse flow.

\section{Conclusion}

This study aimed to propose a procedure to structure the reverse logistics chain for the retail market considering the levels Product Entry Management in the Reverse Logistics Chain; Resource Management in the Reverse Logistics Chain and Performance Management in the Reverse Logistics Chain.

With a focus on the analysis of the structuring of reverse logistics flows in retail trade, a documentary research and data collection were conducted about operational practices in department stores. Three companies had been chosen to be a part in this research. These companies agreed to answer a questionnaire and participate in an interview.

Due to objective and scope delimitation, this work dealt only with the reverse flow of postsale products that return to the trade cycle, since post-consumption products do not usually go through the trade cycle in the reverse channel. The most relevant perspective on reverse logistics in this work, considers the aspects of activities management such as planning and management of returns in reverse flows and their objectives.

Based on the bibliographical review and on the understanding of retail trade we were able to propose a Structure for Process Management in the reverse logistics chain. We believe the main objective of this work has been achieved; we have demonstrated the existence of partially structured reverse flows in a selected group of department stores in Brazil.

It was found that none of the companies define reasons for the rising importance of the reverse logistics development, which shows that they do not know the benefits that may be generated by the implementation of reverse logistics. Additionally, most of the aspects related to the function of transport are not considered and control over reverse logistics performance is not practiced. 
One of the difficulties met throughout the conduction of the research involved obtaining data and information from the three selected companies. Moreover, not all the answers could be proved in practice, since it was not possible to gain access to the product return contracts from the companies.

As suggestions for the improvement and continuity of this work, one could consider the application of this methodology with other types of companies; in a more representative number; and for post-sale and post-consumption reverse logistics chains. Still based on the proposed structuring, one could: (1) research cost formation in the activities of the reverse logistics process; (2) determine performance indicators for the reverse logistics process; (3) conduct a study about financial operations in the reverse logistics process and (4) elaborate structured procedures for information management in the area of reverse logistics.

\section{References}

Autry C. W, Daugherty P. J and Richey R. G. (2000) The challenge of reverse logistics in catalog retailing. International Journal of Physical Distribution and Logistics, vol. 31, n. 1, pp. 26-37.

Assumpção, M. R. P, Chaves, G. L. D and Alcantra, R. L. C. (2008) Performance Measures in Reverse Logistics: The case of a company in the beverages sector. Research Reports in Production Engineering at $U F F$, vol. 8, pp. 2.

Ballou, R. H. (2001) Supply Chain Management. Porto Alegre: Editora Bookman.

Banzato, E. (1998) WMS: Warehouse management system, Imam. São Paulo.

Biazzi, L. F. (2002) Reverse Logistics: what it really is and how it is managed. M. Sc. Dissertation, University of São Paulo, São Paulo, Brazil.

Bowersox, D. J and Closs, D. J. (2001) Corporate Logistics. São Paulo: Editora Atlas.

Brito, E. P. Z, Leite, P. R, Macau, F and Povoa, A. (2005) Determining factors in the structuring of reverse channels: the role of financial gains and corporate image. XXIX ANPAD Meeting, Brasília, Brazil.

Chaves, G. L. D, Martins, R. S, Rocha J. W. F and Opazo, M. A. U. (2005) Diagnosis of Reverse Logistics in the Supply Chain of Processed Food in the west of Paraná. Annals of the XLIII Congress of the Brazilian Rural Economy Society, Ribeirão Preto, Brazil.

Chistopher, M. (1999) Logistics and Supply Chain Management. São Paulo: Editora Pioneira.

De Brito, M. P. (2004) Managing Reverse Logistics or Reversing Logistics Management?, Erasmus University Rotterdam. Rotterdam.

De Koster R.B.M., M.A, De Brito, M.P and Van De Vendel M. A. (2002) How to organize return handling: an exploratory study with nine retailer warehouses. International Journal of Retail and Distribution Management, Holanda.

Dias, S. R. (2003) Marketing Management. São Paulo: Editora Saraiva. 
Figueiredo, F. K, Wanke, P and Fleury, F. P. (2000) Corporate Logistics: the Brazilian perspective. São Paulo: Editora Atlas.

Guarnieri, P. et al. (2006) WMS - Warehouse Management System: proposed adaptation for reverse logistics management. Produção, São Paulo, vol. 16, n. 1.

Horvath A. P, Autry C. W and Wilcox W. E. (2005) Liquidity implications of reverse logistics for retailers: A Markov chain approach. Journal of Retailing, vol. 81, n. 3, pp. 191-203.

Kopicki R, Berge M, Legg L, Dasappa V and Maggioni C. (1993) Reuse and recycling reverse logistics opportunities. Council of Logistics Management, Oak Brook, IL.

Kotler, P. (2000) Marketing Administration: the new millennium edition. São Paulo: Prentice Hall.

Lacerda, L. (2002) Reverse Logistics: A View on the Basic Concepts and Operational Practices. Tecnologística Magazine, pp. 46-50.

Leite, P.R. (1998) Reverse distribution channels. Tecnologística Magazine, Year III, n. 28, pp. 22-27.

Leite, P. R. (2002) Reverse Logistics: a new area in corporate logistics. Tecnologística Magazine, Year VII, n. 78, pp. 102- 109.

Lojas Americanas S.A. (2008) Available at: www.lojasamericanas.com.br.

Martins, V. M. A. (2005) Reverse logistics in Brazil: State-of-the-art. M. Sc. Dissertation. Coordenação dos Programas de Pós-Graduação em Engenharia - COPPE/UFRJ, Rio de Janeiro, Brazil.

Moise M. (2008) The importance of reverse logistics for retail activity. The Amfiteatru Economic journal, vol. 10, issue 24, pp. 192-209.

Reverse Logistics Executive Council - RLEC. (2001) Available at: www.rlec.org.

Rogers, D and Tibben-Lembke, R. (1998) "Going Backwards: Reverse Logistics Trends and Practices". Reverse Logistics Executive Council, University of Nevada, Reno.

Rogers, D and Tibben-Lembke, R. (2001) An examination of reverse logistics practices. Journal of business logistics, vol. 22, n. 2.

Stock, J. (1998) Reverse Logistics Programs. Council of Logistics Management. Florida, University of South.

Valstad C. (2002) Operations of Sears, Roebuck and Co. First International Reverse Logistics Seminar, Council of Logistics Management.

Yin, Robert K. (2001) Case study research - Design and Methods. 2 ed, London: Sage Publications. 